\title{
REQUISITOS DE VALIDADE DE CESSÃO DE DIREITOS HEREDITÁRIOS - LEGITIMIDADE $A D$ CAUSAM PARA AÇÃO REVOGATÓRIA DE DEIXA TESTAMENTÁRIA POR DESCUMPRIMENTO DE ENCARGO - EXONERAÇÃO DE ENCARGO TESTAMENTÁRIO - LIMITES TEMPORAIS E MATERIAIS DOS ENCARGOS
}

\begin{abstract}
Conrado Paulino da Rosa
Advogado especializado em Família e Sucessões. Pós-Doutor em Direito pela Universidade Federal de Santa Catarina (UFSC). Doutor em Serviço Social pela PUCRS.

Mestre em Direito pela UNISC, com a defesa realizada perante a Università Degli

Studi di Napoli Federico II, na Itália. Professor da Graduação e Mestrado em Direito da Fundação Escola Superior do Ministério Público (FMP/RS), em Porto Alegre, onde coordena a Pós-Graduação presencial e EAD em Direito de Família e Sucessões. Professor do Meu Curso, em São Paulo. Presidente da Comissão Especial de Direito de Família e Sucessões da OAB/RS. Membro da Diretoria Nacional do Instituto Brasileiro de Direito de Família - IBDFAM. Presidente da Comissão Especial de Direito de Família e Sucessões da OAB/RS. Autor de obras sobre direito de família e sucessões. E-mail: contato@conradopaulinoadv.com.br. ORCID: https://orcid.org/0000-0001-6625-2671
\end{abstract}

Denise Neulia Franke

Advogada especializada em Direito de Família e Sucessões. Especialista em Direito

Civil, com ênfase em Família e Sucessões pelo IDC, em Porto Alegre. Membro da

Diretoria Executiva do Instituto Brasileiro de Direito de Família - IBDFAM/Seção RS. Vice-Presidente da Comissão Especial de Direito de Família e Sucessões da OAB/RS.

E-mail: denise@conradopaulinoadv.com.br.

Fernanda Rosa Coelho

Advogada. Mestranda em Direito Processual pela Universidade de São Paulo (USP). Pós-Graduanda em Direito de Família e Sucessões pela Fundação Escola Superior do Ministério Público (FMP/RS). E-mail: fernanda@conradopaulinoadv.com.br.

Sumário: 1 Da consulta - $\mathbf{2}$ Relatório: brevíssimas considerações acerca da demanda judicial - $\mathbf{3}$ Aspectos prévios em relação à sucessão de Sr. K - $\mathbf{4}$ Fundamentação - $\mathbf{5}$ Conclusão 


\section{Da consulta}

Trata-se de consulta formulada por XXX, a propósito de ação ordinária pelo procedimento comum, Processo no [...], em tramitação perante a [...], movida por Sr. Y, que busca, em apertadíssima síntese, a revogação do legado instituído em favor da consulente pelo testamento do Sr. K, em razão do suposto descumprimento do encargo estipulado pela deixa testamentária.

Considerando as peculiaridades da demanda, a seguir analisadas, busca a consulente o exame das seguintes questões:

a) A cessão de direitos hereditários apresentada pelo autor é um negócio jurídico perfeito, ou seja, cumpre todos os requisitos de existência, validade e eficácia?

b) $\mathrm{O}$ autor da demanda em análise tem legitimidade ativa para propositura da ação que busca a revogação da liberalidade testamentária por descumprimento de encargo?

c) É possível considerar que o encargo imposto ao legado em favor da consulente foi devidamente cumprido? Há possibilidade de exonerar o legatário do encargo?

\section{Relatório: brevíssimas considerações acerca da demanda judicial}

Trata-se de ação ordinária pelo procedimento comum, Processo ํo [...], em tramitação perante a [...], movida por Sr. Y em desfavor de XXX.

Em breve relato, o demandante busca a revogação do legado instituído em favor da demandada pelo testamento do Sr. K, falecido em 1954, em razão de suposto descumprimento do encargo estipulado pela deixa testamentária, quais sejam, i) a manutenção e conservação da sede da "Fazenda", e ii) a manutenção de serviço de assistência às crianças desamparadas e aos velhos doentes. Aduz que é cessionário dos direitos hereditários do autor da herança, sendo cedente o Sr. Z, conforme escritura pública declaratória de cessão de direitos hereditários, juntada à inicial.

Em contestação, XXX aduziu que cumpriu os encargos testamentários, não obstante venha encontrando dificuldades para tal, mormente em relação à manutenção da sede da "Fazenda", patrimônio tombado que necessita de mão de obra especializada e de alto custo. Indicou também uma série de projetos realizados desde a adjudicação do legado (registrado em favor da requerida em 1969) com fito assistencial, na linha do encargo testamentário. Ressaltou que foi criado o "Instituto Sr. K", como forma de homenagear o autor da herança e atender à sua 
vontade. Alegou, ainda, que o autor carece de legitimidade para propositura da ação nos termos em que realizado, além de impugnar a escritura pública declaratória de cessão de direitos hereditários. Referiu, também, que o direito sub judice encontra-se prescrito, bem como eventual prazo decadencial igualmente já havia transcorrido.

Após despacho ordenando a comprovação da ordem de vocação hereditária do autor em relação ao testador, Sr. Y juntou algumas certidões de nascimento e de casamento, com uma breve explicação sobre a relação de parentesco entre ele e o de cujus. Sobre o ponto, manifestou-se a requerida no sentido da insuficiência dos documentos juntados para a comprovação da legitimidade do autor, reiterando os pedidos contestacionais.

Em nova decisão, o juízo i) manifestou-se sobre o pedido de concessão do benefício da gratuidade da justiça feito por ambas as partes; ii) rejeitou a preliminar de ilegitimidade ativa e de ausência de interesse de agir, suscitadas pela requerida; iii) não reconheceu prescrição ou decadência do direito do autor; e iv) deferiu a produção de prova testemunhal e depoimento pessoal de requerida.

A requerida, então, opôs embargos de declaração a fim de sanar omissão sobre a gratuidade da justiça de XXX, além da fundamentação e motivação do exame da ilegitimidade ad causam do autor, recurso ainda pendente de julgamento. Nesse ponto que se encontra o processo quando da consulta.

\section{Aspectos prévios em relação à sucessão de Sr. K}

Diante da natureza dos questionamentos apresentados, imperioso que, antes de adentrar aos aspectos específicos da consulta proposta, sejam dirimidas questões preliminares acerca da sucessão e, principalmente, dos herdeiros e legatários do Sr. K. Isso porque a capacidade sucessória dos envolvidos é tema que permeia todo o debate proposto e, portanto, merece maior esclarecimento.

Importante lembrar que, nos termos do art. 1.787 do Código Civil vigente, regula a sucessão e a legitimação para suceder a lei vigente ao tempo da abertura daquela. Logo, como o testador, Sr. K, faleceu no ano de 1954, aplica-se à sua sucessão as regras do Código Civil de 1916, que será utilizado para as anotações que seguem.

$\mathrm{Na}$ legislação civil revogada, o parentesco em linha colateral ou transversal era limitado até o sexto grau, ${ }^{1}$ sendo sua capacidade sucessória restrita ao quarto

1 Art. 331 do Código Civil de 1916: "São parentes, em linha colateral, ou transversal, até o sexto grau, as pessoas que provém de um só tronco, sem descenderem umas das outras”. O Código Civil de 2002 reduziu esta limitação ao quarto grau, nos termos do seu art. 1.592. 
grau, ${ }^{2}$ de modo que os de grau mais próximo excluíam os mais remotos, ressalvado o direito de representação dos filhos de irmãos (sobrinhos). ${ }^{3}$ Ainda, pela dicção legal da época, os colaterais apenas seriam herdeiros se o falecido não tivesse deixado ascendentes, descendentes, cônjuge ou testamento que Ihes afastassem da sucessão. ${ }^{4}$

Não obstante, importa lembrar que a sucessão pode ser operacionalizada, basicamente, de duas formas: por lei ou por disposição de última vontade. ${ }^{5} \mathrm{~A}$ partir disso, tem-se que, falecendo a pessoa sem deixar testamento, sua herança é transmitida aos chamados herdeiros legítimos, na forma preconizada pelo art. 1.603 do Código Civil de $1916,{ }^{6}$ o que ocorre também com aqueles bens que não forem comtemplados em eventual testamento. ${ }^{7}$

Em relação aos sucessores legítimos, imprescindivel a diferenciação entre herdeiros necessários e facultativos, sendo os primeiros - no diploma civilista de 1916 - descendentes e ascendentes, e os demais herdeiros pertencentes à segunda categoria. ${ }^{8}$

Tal classificação impacta diretamente os limites do testamento, uma vez que a presença de herdeiros necessários importa em restrição à autonomia do disponente, visto que metade dos bens da herança Ihes será reservada. ${ }^{9}$ Essa reserva

2 Art. 1.612 do Código Civil de 1916: "Se não houver cônjuge sobrevivente, ou ele incorrer na incapacidade do artigo 1.611, serão chamados a suceder os colaterais até o quarto grau”. Norma equivalente ao art. 1.839 do Código Civil de 2002.

3 Art. 1.613 do Código Civil de 1916: "Na classe dos colaterais, os mais próximos excluem os mais remotos, salvo o direito de representação concedido aos filhos de irmãos". Norma equivalente ao art. 1.840 do Código Civil de 2002.

4 Art. 1.725 do Código Civil de 1916: "Para excluir da sucessão o cônjuge ou os parentes colaterais, basta que o testador disponha do seu patrimônio, sem os contemplar".

5 Nos termos do art. 1.573 do Código Civil de 1916: “A sucessão dá-se disposição de última vontade, ou em virtude de lei”. Norma equivalente ao art. 1.786 do Código Civil de 2002.

6 Art. 1.603 do Código Civil de 1916: “A sucessão legítima defere-se na ordem seguinte: I - aos descendentes; II - aos ascendentes; III - ao cônjuge sobrevivente; IV - aos colaterais; V - aos Municípios, ao Distrito Federal ou à União". Regrando a matéria de forma distinta é o art. 1.829 do Código Civil de 2002: “A sucessão legítima defere-se na seguinte ordem: I - aos descendentes, em concorrência com o cônjuge sobrevivente, salvo se casado este com o falecido no regime da comunhão universal, ou no da separação obrigatória de bens (art. 1.640, parágrafo único); ou se, no regime da comunhão parcial, o autor da herança não houver deixado bens particulares; II - aos ascendentes, em concorrência com o cônjuge; III - ao cônjuge sobrevivente; IV - aos colaterais".

7 Art. 1.574 do Código Civil de 1916: "Morrendo a pessoa sem testamento, transmite-se a herança a seus herdeiros legítimos. Ocorrerá outro tanto quanto aos bens que não forem compreendidos no testamento". Norma equivalente ao art. 1.788 do Código Civil de 2002.

8 Importante reiterar que esse era o regramento à luz do Código Civil de 1916. Isso porque com o Código Civil de 2002 o cônjuge passou a figurar no rol de herdeiros necessários, conforme preconiza o seu art. 1.845.

9 Art. 1.721 do Código Civil de 1916: "O testador que tiver descendente ou ascendente sucessível, não poderá dispor de mais da metade de seus bens; a outra pertencerá de pleno direito ao descendente e, em sua falta, ao ascendente, dos quais constitui a legítima, segundo o disposto neste Código”. O Código Civil de 2002 inclui o cônjuge como herdeiro necessário (art. 1.845) e determina que "pertence aos herdeiros necessários, de pleno direito, a metade dos bens da herança, constituindo a legítima”. 
é chamada de legítima. Assim, alguém inserido nessa estrutura apenas pode dispor de $50 \%$ de seus bens em testamento, sendo essa parcela nominada "parte disponível". Contrario sensu, ao sujeito que não possui herdeiros necessários permite-se testar a integralidade de seu patrimônio sem qualquer constrangimento.

É justamente esse o caso sob análise.

Em que pese a ausência de elementos suficientes nos autos para que se possa aferir toda a genealogia do testador e das partes, com os documentos que instruem o feito é possível identificar a relação de parentesco dos envolvidos entre si e com Sr. K (testador), como demonstrado a seguir: ${ }^{10}$

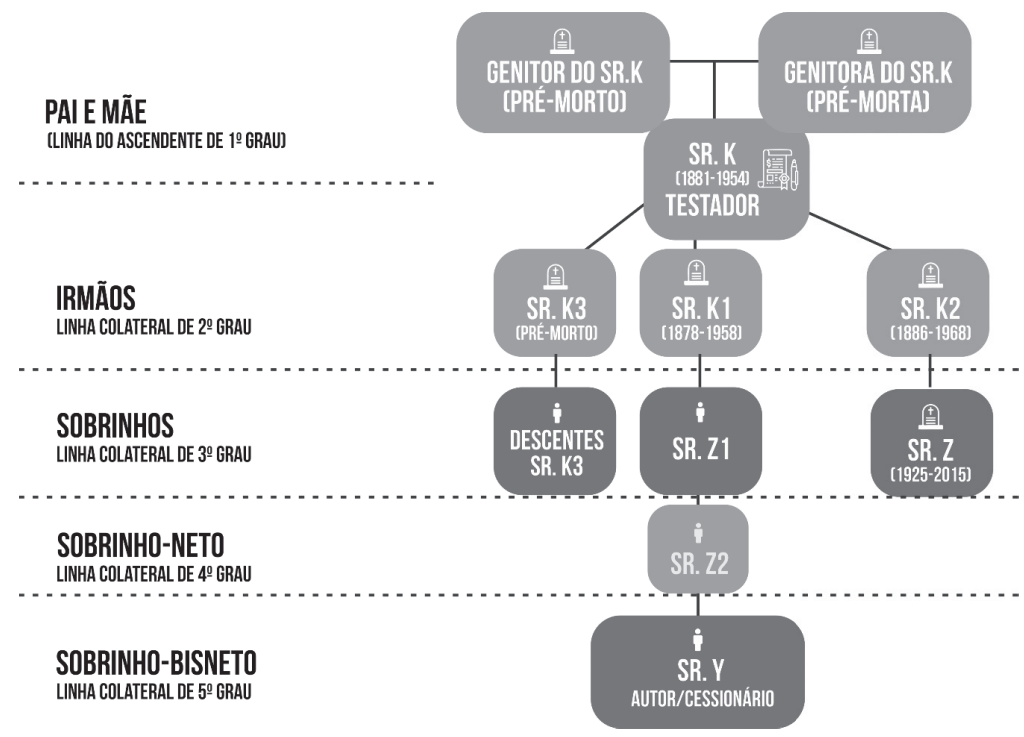

Nota-se que o testador não possuía ascendentes vivos ou descendentes e, mesmo que fosse casado, ao tempo da abertura da sucessão o cônjuge não era considerado herdeiro necessário. Por isso, o de cujus optou por dispor da integralidade de seu patrimônio em sua cédula testamentária.

Dessa forma, a partir do momento em que estipulou testamento, todos aqueles beneficiados pelas suas disposições passaram a ser sucessores a título singular, ou seja, cada um sucedeu apenas em relação aos bens que ali the foram

10 As datas indicadas no organograma se referem ao ano de nascimento e óbito de cada pessoa, conforme os dados extraídos dos documentos dos autos. Ressalta-se que, dado à insuficiência dos dados contidos no processo, não foi possível identificar a informação de todos os sujeitos, motivo pelo qual nem todos possuem tal indicação, de modo que não se pode afirmar que eles já faleceram, tampouco que ainda vivem. 
indicados, não na totalidade da herança. Sobre o ponto, vale a lição de Cristiano Chaves de Farias e Nelson Rosenvald:

O sucessor pode receber o patrimônio transmitido a título universal ou singular.

Quando o beneficiário adquire o patrimônio a título universal, chama-se herdeiro. [...] O herdeiro, portanto, é aquele que continuará as relações patrimoniais, titularizando um percentual do total transmitido. É o exemplo do sucessor que recebe vinte, trinta ou quarenta por cento do patrimônio do autor da herança.

Lado outro, se o sucessor recebe o patrimônio a título singular, é designado como legatário [...]. Este é o que recebe um bem especifico, certo e determinado, móvel ou imóvel. É o caso de alguém que é beneficiado com uma casa ou um automóvel pelo autor da herança, por meio de testamento.

A diferença é elementar: o herdeiro sucede na totalidade do patrimônio transferido, quando for único, ou em cota-parte dele, quando há mais de um (título universal); o legatário sucede em bens ou valores certos e determinados (título singular). ${ }^{11}$

Outrossim, analisando novamente as relações de parentesco expostas no gráfico acima, percebe-se com certa facilidade que ainda que o testador tivesse falecido ab intestato, ou seja, sem ter realizado testamento, seriam seus herdeiros os irmãos Sr. K1 e Sr. K2, além dos filhos de Sr. K3 (irmão pré-morto do testador), por representação do pai.

A pertinência e as implicações dessas conclusões preliminares são ressaltadas no curso deste parecer e aprofundadas na medida em que contribuírem com a resposta à consulta.

\section{Fundamentação}

\subsection{Da escritura pública declaratória de cessão de direitos hereditários juntada pelo demandante}

A resposta ao primeiro quesito da consulta, acerca da cessão de direitos hereditários apresentada pelo autor, passa pela análise do documento em diferentes

11 FARIAS, Cristiano Chaves de; ROSENVALD, Nelson. Curso de direito civil: sucessões. 7. ed. Salvador: JusPodivm, 2021. p. 60. 
aspectos. Com efeito, em se tratando de um negócio jurídico, deve-se examiná-lo sob o prisma da existência, validade e eficácia. ${ }^{12}$ Acerca do plano da existência, percebese sem grande dificuldade que o documento atende aos requisitos para tanto. ${ }^{13}$

Por tal razão, cumpre analisar com maior profundidade se o documento apresentado atende aos requisitos para sua validade. Tais requisitos vêm apontados no art. 104 do Código Civil de 2002, quais sejam, i) agente capaz; ii) objeto lícito possível, determinado ou determinável; e iii) forma prescrita ou não defesa em lei. Passa-se, então, ao exame de cada um desses elementos.

\subsubsection{Da forma da cessão de direitos hereditários}

Diferentemente do que ocorre com a sucessão e a legitimação para suceder, que obedecem à regra da lei vigente ao tempo da morte do autor da herança (CC/2002, art. 1.787), os negócios jurídicos ${ }^{14}$ devem ser analisados pela lei vigente ao tempo de sua celebração. Aplica-se a regra de que o tempo rege o ato (tempus regit actum), ou seja, a lei vigente ao tempo do fato é a que regulamenta a relação entre as partes envolvidas. ${ }^{15}$

Sendo a cessão de direitos hereditários um negócio jurídico e, em relação especificamente à cessão aqui analisada, lavrada em 8.9.2011, ${ }^{16}$ aplicam-se à análise as regras do Código Civil de 2002, a legislação hoje vigente.

Em linhas gerais, “a cessão de direitos hereditários trata-se de um contrato bilateral, translativo, gratuito ou oneroso e, via de regra, em caráter aleatório, onde o herdeiro transfere a totalidade ou cotas da herança de que é titular". ${ }^{17}$

12 Os critérios elencados se baseiam na teoria desenvolvida por Pontes de Miranda, notadamente em seu Tratado de direito privado, e seguida pela doutrina majoritária, a chamada teoria da escada ponteana.

13 Conforme Marcos Bernardes de Mello, “no plano de existência não se cogita de invalidade ou eficácia do fato jurídico, importa, apenas, a realidade da existência. Tudo, aqui, fica circunscrito a se saber se o suporte fático suficiente se compôs, dando ensejo à incidência”. Cf. MELLO, Marcos Bernardes. Teoria do fato jurídico: plano de existência. 10. ed. São Paulo: Saraiva, 1999. p. 83. Muito embora a doutrina não seja pacífica quanto aos elementos existenciais, é possível identificá-los. Assim, são pressupostos de existência do negócio jurídico: i) agente; ii) objeto; iii) forma; iv) vontade exteriorizada. Cf. FARIAS, Cristiano Chaves de; ROSENVALD, Nelson. Curso de direito civil: parte geral e LINDB. 19. ed. Salvador: JusPodivm, 2021. p. 695.

14 Incluindo o negócio jurídico como espécie de ato jurídico, vale a lição de Cristiano Chaves de Farias e Nelson Rosenvald: "[...] os atos jurídicos, compreendidos em sentido amplo, dizem respeito aos atos decorrentes da vontade humana. E que essa vontade humana pode ser exteriorizada no sentido de aderir a efeitos jurídicos concretos previstos na norma jurídica (ato jurídico stricto sensu) ou pode ser dirigida à criação de concretos efeitos jurídicos (negócios jurídicos)”. Cf. FARIAS, Cristiano Chaves de; ROSENVALD, Nelson. Curso de direito civil: parte geral e LINDB. 19. ed. Salvador: JusPodivm, 2021. p. 680.

15 Nesse sentido: STJ, 2ª T. REsp no 1.798.746/PE. Rel. Min. Francisco Falcão, j. 24.11.2020. DJe, 1ํ dez. 2020.

16 Documento juntado aos autos.

17 ROSA, Conrado Paulino da; RODRIGUES, Marco Antônio. Inventário e partilha. 3. ed. Salvador: JusPodivm, 201. p. 69. 
Em relação à forma, o art. 1.793 do Código Civil de $2002^{18}$ dispõe que a cessão deve ser realizada por escritura pública. Isso decorre da regra trazida pelo art. 80 do Código Civil de 2002, ${ }^{19}$ que impõe à herança o tratamento como de um bem imóvel.

Não há dúvida de que o documento apresentado nos autos é, de fato, uma escritura pública. Todavia, o Provimento Conjunto no 93/2020,20 emitido pelo Presidente do Tribunal de Justiça do Estado de Minas Gerais e o Corregedor-Geral de Justiça do Estado de Minas Gerais, traz regras específicas para lavratura de escritura pública de cessão de direitos hereditários em seu Capítulo III, do Título III. Por esse motivo, a análise do cumprimento dos requisitos formais do documento questionado deve ser feita à luz do regramento citado.

De início, vale atentar ao fato de que o provimento conjunto exige do tabelião que faça constar na escritura algumas informações específicas relativas às peculiaridades da cessão de direitos hereditários:

Art. 192. Para a lavratura do de escritura pública de cessão de direitos à sucessão aberta, o tabelião de notas deve cientificar o adquirente e nela consignar que a cessão compreende não só o quinhão ou a quota ideal atribuível ao cedente nos bens, mas também, proporcionalmente, as dívidas do espólio até o limite das forças da herança. [...]

$\S 2$ ○ 0 tabelião de notas fará constar da escritura que eventuais direitos posteriormente conferidos ao herdeiro cedente em consequência de substituição ou de direito de acrescer se presumem não abrangidos pela cessão.

§3ํ Na escritura de cessão de direitos hereditários, o tabelião de notas fará constar que o cessionário deverá habilitar o título no procedimento de inventário. (Grifos nossos)

18 Art. 1.793 do Código Civil de 2002: "O direito à sucessão aberta, bem como o quinhão de que disponha o co-herdeiro, pode ser objeto de cessão por escritura pública".

19 Art. 80 do Código Civil de 2002: “Consideram-se imóveis para os efeitos legais: [...] II - o direito à sucessão aberta".

20 "O Provimento Conjunto n. 93/2020, alterado pelo Provimento Conjunto n. 100/2021, institui o Código de Normas da Corregedoria-Geral de Justiça do Estado de Minas Gerais, que regulamenta os procedimentos e complementa os atos legislativos e normativos referentes aos serviços notariais e de registro do Estado de Minas Gerais" (Disponível em: http://www8.tjmg.jus.br/institucional/at/pdf/vc00932020.pdf). Ressalta-se que o Provimento no 260/CGJ/2013, alterado em diversas oportunidades e revogado pelo Provimento Conjunto no 93/2020, tinha como escopo codificar os atos normativos da Corregedoria-Geral de Justiça do Estado de Minas Gerais relativos aos serviços notariais e de registro e já trazia as previsões específicas sobre a forma da escritura pública de cessão de direitos hereditários. Em que pese a ausência de regramento dessa natureza quando da lavratura da escritura pública em análise (no ano de 2011), importa realizar o exame de sua forma à luz desta normativa, visto que reflete em larga medida a prática da época, tendo influência também na exigibilidade contemporânea do documento. 
No documento apresentado pelo autor não consta nenhuma das observações acima transcritas, que, pela literalidade do dispositivo, possuem caráter obrigatório.

0 §5 do mesmo artigo dispõe que,

para a lavratura da escritura pública de cessão de direitos hereditários, seja a título gratuito ou oneroso, devem ser apresentados os comprovantes de quitação dos tributos incidentes, conforme previsão na legislação estadual ou municipal, os quais devem ser arquivados na serventia.

Veja que a quitação dos tributos relativos à transação da cessão de direitos hereditários é um requisito para a própria lavratura da escritura pública, ou seja, para a validade do documento. Essa ideia é reforçada pelo art. 187 do mesmo provimento, que se refere às escrituras públicas de transferência de direitos relativos a imóvel. Como dito, sendo a herança considerada um bem imóvel, tal dispositivo se aplica integralmente à transmissão de direitos hereditários:

Art. 187. São requisitos documentais inerentes à regularidade de escritura pública que implique transferência de domínio ou de direitos relativamente a imóvel, bem assim como constituição de ônus reais: I - apresentação de comprovante de pagamento do imposto de transmissão, havendo incidência, salvo quando a lei autorizar o recolhimento após a lavratura, fazendo-se, nesse caso, expressa menção ao respectivo dispositivo legal; [...]

§4 o caso do Imposto sobre Transmissão Causa Mortis e Doação de Quaisquer Bens ou Direitos - ITCD, somente a apresentação da Declaração de Bens e Direitos, contendo a respectiva Certidão de Pagamento de Desoneração emitida pela Secretaria da Fazenda - SEFAZ, atende ao previsto no inciso I deste artigo, sendo, no entanto, insuficiente apenas a demonstração da guia Documento de Arrecadação Estadual - DAE de pagamento do imposto, nos termos da Lei estadual no 14.941, de 29 de dezembro de 2003, que “dispõe sobre o Imposto sobre Transmissão Causa Mortis e Doação de Quaisquer Bens ou Direitos - ITCD". (Grifos nossos)

Nesse mesmo sentido é a Lei no 7.433/1985, vigente ao tempo da feitura da cessão de direitos e que dispunha justamente sobre os requisitos para a lavratura de escrituras públicas: 
Art. $1^{\circ}[\ldots]$

§2ํㅡ O Tabelião consignará no ato notarial a apresentação do documento comprobatório do pagamento do Imposto de Transmissão inter vivos, as certidões fiscais e as certidões de propriedade e de ônus reais, ficando dispensada sua transcrição.

Acerca da incidência da tributação na cessão de direitos hereditários, vale uma breve nota sobre a sua característica: “sendo gratuita, a cessão de herança é equiparada a uma doação; sendo onerosa, ela tem natureza de uma compra e venda". ${ }^{21}$ Assim, a tributação dependerá do modo em que se deu a cessão: quando for gratuita, incide o imposto sobre transmissão causa mortis e doação de quaisquer bens ou direitos (ITCD); ${ }^{22}$ quando for onerosa, incide o imposto de transmissão de bens imóveis intervivos (ITBI). ${ }^{23}$

No documento apresentado pelo autor, não há qualquer menção ao modo em que se deu a cessão de direitos hereditários (se gratuito ou oneroso), tampouco aos comprovantes de recolhimento do imposto sobre a operação, indispensável para a validade do ato.

Além da influência no recolhimento do imposto, a informação sobre o modo de cessão (gratuita ou onerosa) é relevante, pois dela decorre outra obrigação que deverá ser registrada na escritura pública, nos termos do art. 195 do provimento conjunto: "nas cessões de direitos hereditários onerosas a terceiros estranhos à sucessão, deverá constar da escritura a previsão do direito de preferência dos demais coerdeiros e/ou meeiro sobrevivente, nos termos do art. 1.794 do Código Civil”.

Outro aspecto sobre o documento deve ser levado em conta também para a análise de sua validade: o momento em que celebrado. Com efeito, a cessão de direitos hereditários pode ser realizada desde a abertura da sucessão até que se ultime partilha. ${ }^{24}$

A vedação à cessão de direitos hereditários anteriormente à morte do autor da herança tem base na proibição do chamado pacta corvina, expresso no art. 426

21 FARIAS, Cristiano Chaves de; ROSENVALD, Nelson. Curso de direito civil: sucessões. 7. ed. Salvador: JusPodivm, 2021. p. 217.

22 “A Lei n. 14.941, de 29 de dezembro de 2003, dispõe sobre o Imposto sobre Transmissão Causa Mortis e Doação de Quaisquer Bens ou Direitos (ITCD); o Decreto n. 43.981, de 3 de março de 2005, regulamenta o ITCD no estado de Minas Gerais" (Disponível em: http://www.fazenda.mg.gov.br/empresas/legislacao_ tributaria/itcd//index.html).

23 “A Lei n. 5.492, de 28 de dezembro de 1988, institui o Imposto sobre Transmissão de Bens Imóveis por ato oneroso Inter Vivos (ITBI); o Decreto n. 17.026, de 29 de novembro de 2018, regulamenta o ITBI no estado de Minas Gerais" (Disponível em: https://www.cmbh.mg.gov.br/atividade-legislativa/pesquisarlegislacao/decreto/17026/2018).

24 VELOSO, Zeno. Código Civil comentado. 8. ed. São Paulo: Saraiva, 2012. p. 2018. 
do Código Civil de 2002, ${ }^{25}$ que proíbe a negociação de herança de pessoa viva. Por outro lado, "após efetivar a partilha, o titular estará dispondo de direito próprio e não mais de direito hereditário, assumindo o negócio natureza de verdadeira compra e venda ou de doação". ${ }^{26}$

Conforme consta dos autos, o inventário e adjudicação dos bens ${ }^{27}$ por ocasião do falecimento do Sr. K foi encerrado em $1967,{ }^{28}$ ao passo que a "escritura pública declaratória de cessão de direitos hereditários" (nos exatos termos em que nominada) foi lavrada em 8.9.2011.

Logo, quando da celebração do negócio entre as partes, não havia mais que se falar em "direitos hereditários sobre o legado dos bens de Sr. K" (conforme consta da escritura pública). Eventual negociação entre as partes, conforme lição doutrinária citada, ${ }^{29}$ teria por objeto um direito próprio, caracterizando-se como compra e venda (se onerosa) e doação (se gratuita).

Sobre esse aspecto, interessante julgado do Tribunal de Justiça do Rio Grande do Sul ao analisar a possibilidade de realização de cessão de direitos hereditários por meio de ação declaratória. Na oportunidade, a 8a Câmara Cível, além decidir pela inviabilidade da ação meramente declaratória para formalização da cessão, como pretendido, ainda perquiriu sobre o momento em que realizado o negócio, asseverando como segue:

[...] no caso, considerando que já ultimado o inventário há mais de 20 anos e que já transmitida a propriedade do imóvel inventariado aos herdeiros no álbum imobiliário, não mais se revela cabível efetuar cessão de direitos hereditários a terceiro, para o fito de transmitir diretamente ao pretenso cessionário - com quem, em verdade, os requerentes firmaram contrato de compra e venda por instrumento particular há 3 anos - a propriedade de bem que foi objeto do inventário,

25 Art. 426 do Código Civil de 2002: “Não pode ser objeto de contrato a herança de pessoa viva".

26 FARIAS, Cristiano Chaves de; ROSENVALD, Nelson. Curso de direito civil: sucessões. 7. ed. Salvador: JusPodivm, 2021. p. 229.

27 Ressalta-se que em razão de serem os legatários todos herdeiros singulares, como já referido, ou seja, herdam apenas em relação àquele determinado bem ou valor, não há efetivamente uma partilha dos bens do espólio, mas sim a adjudicação do seu legado por cada um dos legatários. Não obstante, para os fins aqui pretendidos, entende-se que ambas situações têm o mesmo efeito: transferir integralmente o patrimônio do falecido aos herdeiros.

28 Conforme informação extraída da contestação. Ressalta-se que o registro dos imóveis legados à XXX foram realizados em 28.8.1969, o que demonstra que o inventário de Sr. K e adjudicação dos bens pelos legatários ocorreu em momento anterior a esse.

29 Em reforço ao já citado: “[...] a cessão somente poderá ser efetuada antes da partilha, pois, se o for após a partilha, ter-se-á uma alienação de coisa certa e determinada". Cf. VIEIRA, lacyr de Aguilar. Cessão de direitos e cessão de pretensões no direito brasileiro. In: TEPEDINO, Gustavo; FACHIN, Luiz Edson (Org.). Doutrinas essenciais - Obrigações e contratos. São Paulo: Revista dos Tribunais, 2011. v. 2. 
a qual já foi consolidada em favor dos herdeiros, pessoalmente, junto ao Registro de Imóveis. Desse modo, pretendendo a recorrente, então co-proprietária, juntamente com seu cônjuge, transmitir a terceira a fração do imóvel que lhe tocou por ocasião da partilha no inventário, em 1990, em virtude de contrato particular de compra e venda celebrado no ano de 2012, deverá lançar mão do negócio jurídico próprio para tanto, com o recolhimento dos respectivos tributos, não havendo falar na possibilidade de que seja simplesmente formalizada uma cessão de direitos hereditários para tanto. ${ }^{30}$ (Grifos nossos)

Ainda, importante referir o apontado doutrinariamente no sentido de que há certa confusão entre a cessão e a renúncia de direitos hereditários, havendo quem refira aos institutos como renúncia translativa e renúncia abdicativa, respectivamente. ${ }^{31}$ Com efeito, a renúncia, diferentemente da cessão, sempre terá caráter abdicativo, e pode ser entendida como “a demissão da qualidade de herdeiro". ${ }^{32}$

Ao abdicar da herança que Ihe foi transferida automaticamente, o herdeiro ou legatário passa a ser tratado como se nunca tivesse sido sucedido (efeitos ex tunc), não podendo os seus sucessores representá-lo, ${ }^{33}$ e seu quinhão é acrescido imediatamente pelos demais coerdeiros, ${ }^{34}$ a título de direito de acrescer. Ou seja, diferentemente da cessão, na renúncia não se indica um beneficiário para sua cota hereditária, uma vez que seu quinhão retornará ao monte-mor.

30 TJRS, 8aㅡâmara Cível. Ap. Cív. no 70065754392, Rel. Des. Luiz Felipe Brasil Santos, j. 19.11.2015.

31 Nas palavras de Caio Mario da Silva Pereira, “costuma-se distinguir da renúncia abdicativa a chamada renúncia translativa, que implica a transmissão a determinada pessoa, designada pelo renunciante. A primeira (abdicativa) é verdadeira renúncia, ao passo que a segunda (translativa ou translatícia) envolve duas declarações de vontade, importando em aceitação e alienação simultânea ao favorecido. Daí dizer-se que é renúncia de nome, mas em verdade é aceitação". Cf. PEREIRA, Caio Mario da Silva. Instituições de direito civil: direito das sucessões. 27. ed. Rio de Janeiro: Forense, 2020. p. 54.

32 MALUF, Carlos Alberto Dabus; MALUF, Adriana Caldas do Rego Farias Dabus. Curso de direito das sucessões. São Paulo: Saraiva, 2013. p. 137. Cristiano Chaves de Farias e Nelson Rosenvald conceituam a renúncia (ou repúdio) como “o ato jurídico em sentido estrito, unilateral, pelo qual o herdeiro declara não aceitar o patrimônio do falecido, repudiando a transmissão automática que a lei operava em seu favor, despojando-se, por conseguinte, da sua titularidade. É, enfim, a rejeição ao recebimento de uma herança". Cf. FARIAS, Cristiano Chaves de; ROSENVALD, Nelson. Curso de direito civil: sucessões. 7. ed. Salvador: JusPodivm, 2021. p. 247.

33 Art. 1.811 do Código Civil de 2002: “Ninguém pode suceder, representando herdeiro renunciante. Se, porém, ele for o único legítimo da sua classe, ou se todos os outros da mesma classe renunciarem a herança, poderão os filhos vir à sucessão, por direito próprio, e por cabeça".

34 Art. 1.810 do Código Civil de 2002: "Na sucessão legítima, a parte do renunciante acresce à dos outros herdeiros da mesma classe e, sendo ele o único desta, devolve-se aos da subsequente". Exemplificando: havendo cinco herdeiros, se um deles repudia a transmissão, os outros quatro recolhem a sua cota. No caso, não haverá sucessão por representação (também chamada de sucessão por estirpe), que se restringe aos casos de indignidade, de deserdação e pré-morte. Cf. FARIAS, Cristiano Chaves de; ROSENVALD, Nelson. Curso de direito civil: sucessões. 7. ed. Salvador: JusPodivm, 2021. p. 254. 
Essa observação se faz relevante no presente caso pois na escritura pública em análise consta que "Sr. Z cede em favor de Sr. Y [...] todos os direitos hereditários sobre o legado dos bens de Sr. K [...] abdicando da parte legítima a que tem direito em favor de Sr. Y [...]". Essa assertiva dá azo à interpretação de que, em verdade, o documento trata de uma renúncia e não de uma cessão, que possui distinção, inclusive, acerca da forma, o que redundaria na inaplicabilidade dos aspectos aqui expostos ao documento.

No entanto, novamente nos termos do provimento conjunto supracitado e em consonância com a legislação e doutrina nacional, "a renúncia de direitos hereditários somente pode ser feita, pura e simples, em favor do monte-mor". ${ }^{35}$ Ainda, "a renúncia em que se indique beneficiário constitui cessão de direitos hereditários e deve observar a forma prevista para este ato, seja a título gratuito ou oneroso" ${ }^{36}$ Reforça-se, assim, a necessidade de atendimento aos critérios formais aqui examinados.

Destarte, percebe-se, após o exposto, que o documento juntado pelo autor, nominado de "Escritura pública declaratória de cessão de direitos hereditários", não está de acordo com a forma exigida para o ato, uma vez que carece de várias informações obrigatórias que devem estar expressas na cédula do negócio jurídico. Assim, descumpre o disposto no art. 104, inc. III, do Código Civil de 2002 o que, conforme 0 art. 166 , inc. IV, ${ }^{37}$ do mesmo diploma, redunda na nulidade do negócio jurídico.

\subsubsection{Da capacidade do cedente na cessão de direitos hereditários}

A capacidade do agente, preconizada no art. 104, inc. I, do Código Civil de 2002, refere-se ao regime de capacidades instituído pelo mesmo diploma legal. Com efeito, não há a priori qualquer evidência que possa pôr em risco o discernimento do cedente, a despeito de sua idade avançada quando da lavratura do documento em análise. ${ }^{38}$

Isso porque o ordenamento jurídico contemporâneo traz a premissa de que a capacidade é regra e a incapacidade a exceção, de modo que são listadas objetivamente as hipóteses de restrição da plena capacidade, esclarecendo ser

Art. 194 do Provimento Conjunto no 93/2020, do estado de Minas Gerais.

Art. 194, $\S 1$ ํ do Provimento Conjunto no 93/2020, do estado de Minas Gerais.

37 Art. 166 do Código Civil de 2002: “É nulo o negócio jurídico quando: [...] IV - não revestir a forma prescrita em lei".

38 Ante a informação do nascimento de Sr. Z, cedente, no ano de 1925, e sendo a escritura pública datada em 2011, a idade do cedente era de aproximadamente 86 anos na época da celebração do negócio jurídico. 
excepcional a limitação ao exercício dos atos civis. ${ }^{39}$ Sobre esse aspecto, percebese que na escritura pública em análise consta que o cedente está "[...] em seu juízo perfeito, livre sem qualquer coação, sugestão ou induzimento [...]", o que deve ser tomado como verdadeiro para a presente análise, inexistentes fatos ou evidências que apontem em sentido contrário.

Todavia, a capacidade do agente para realização de negócios jurídicos não se resume a esse aspecto, sobretudo à luz das peculiaridades que permeiam o negócio em questão (repisa-se, cessão de direitos hereditários). Nessa ótica, deve-se analisar também a legitimação do sujeito em relação ao ato por ele formulado.

Pode-se dizer que "a legitimação é uma espécie de capacidade jurídica específica para certas situações elencadas em tipos normativos. Ou seja, é um requisito específico (normativamente exigido) para a prática de determinados atos específicos". ${ }^{40}$ Logo, mesmo que esteja capacitada plenamente, a pessoa poderá não estar habilitada para a prática de determinados atos da vida jurídica, para os quais a norma estabeleça requisitos específicos: "somente poderá praticá-los se atender aos elementos especificados pela norma". ${ }^{41}$

É o que se observa com a cessão de direitos hereditários: para que o sujeito possa ceder sua cota hereditária sobre determinada sucessão aberta, deve, por óbvio, ser herdeiro do autor da herança.

Desta feita, “[...] pode-se afirmar, quanto à cessão da herança, que há necessidade, além dos requisitos próprios aos atos jurídicos em geral, que o cedente seja herdeiro e possua capacidade de dispor de bens, ou seja, a capacidade para alienar [...]". ${ }^{42}$ Isso porque a cessão de direitos hereditários "trata-se de ato próprio de herdeiro, a ensejar aceitação tácita da herança e dupla transmissão: i) mortis causa, do autor da herança para o cedente; ii) inter vivos, do cedente para o cessionário". ${ }^{43}$

Retomam-se aqui as conclusões colhidas no tópico 3 do presente parecer, quando da análise dos sucessores do Sr. K, testador e autor da herança.

39 FARIAS, Cristiano Chaves de; ROSENVALD, Nelson. Curso de direito civil: parte geral e LINDB. 19. ed. Salvador: JusPodivm, 2021. p. 390.

40 FARIAS, Cristiano Chaves de; ROSENVALD, Nelson. Curso de direito civil: parte geral e LINDB. 19. ed. Salvador: JusPodivm, 2021. p. 388. Complementam os autores: “a legitimação é, portanto, um plus na capacidade. Trata-se de um requisito específico, extra, exigido para a prática de determinados atos específicos da vida civil".

41 FARIAS, Cristiano Chaves de; ROSENVALD, Nelson. Curso de direito civil: parte geral e LINDB. 19. ed. Salvador: JusPodivm, 2021. p. 388. Washington de Barros Monteiro explica que a legitimação é uma inibição para a prática de determinados atos jurídicos, em virtude de posição especial do sujeito em relação a certos bens, pessoas ou interesses, ao passo que a capacidade diz respeito à possibilidade genérica de praticar atos jurídicos pessoalmente. Cf. MONTEIRO, Washington de Barros. Curso de direito civil: parte geral. 39. ed. São Paulo: Saraiva, 2003. p. 60.

42 VIEIRA, lacyr de Aguilar. Cessão de direitos e cessão de pretensões no direito brasileiro. In: TEPEDINO, Gustavo; FACHIN, Luiz Edson (Org.). Doutrinas essenciais - Obrigações e contratos. São Paulo: Revista dos Tribunais, 2011. v. 2.

43 TEPEDINO, Gustavo; NEVARES, Ana Luiza Maia; MEIRELES, Rose Melo Vencelau. Fundamentos do direito civil: direito das sucessões. 2. ed. Rio de Janeiro: Forense, 2021. p. 38. 
Como já observado e sem fazer maiores digressões a respeito, a fim de evitar tautologia, o autor da herança dispôs da integralidade de seu patrimônio em testamento, sendo que nenhum dos legados foi deixado em favor de Sr. Z (cedente). Outrossim, ainda que fosse considerada a ordem de vocação hereditária, seriam herdeiros do testador seus irmãos, Sr. K1 e Sr. K2, e seus sobrinhos, filhos do seu irmão pré-morto, Sr. K3, e representação do pai.

Ou seja, em nenhum dos cenários possíveis o cedente, Sr. Z, seria “legítimo herdeiro de Sr. K", como consta na escritura pública em análise. Por tal razão, o cedente carece de legitimidade para "ceder, transferir, quaisquer e todos os direitos hereditários sobre o legado dos bens de Sr. K [...]", inclusive "abdicando da parte legítima a que tem direito", como expresso na escritura pública juntada pelo autor.

Além disso, como também já explicado, à época do falecimento do Sr. K (sob a égide do Código Civil de 1916), apenas eram considerados herdeiros necessários, os quais fariam jus à legítima (que o cedente expressa abdicar em favor do cessionário), os ascendentes e descendentes. Logo, se Sr. Z jamais foi herdeiro ou legatário de Sr. K, tampouco seria herdeiro necessário.

Importante registrar que, olhando novamente para o demonstrativo de parentesco colacionado no tópico 3, eventuais bens ou valores que pertenciam originariamente a Sr. $\mathrm{K}$ apenas poderiam acabar na posse e/ou propriedade do cedente por ocasião da morte de seu genitor, esse sim legatário do testador.

Explica-se: concluído o inventário e adjudicados os bens de Sr. $\mathrm{K}$ - falecido em 1954 - pelos legatários, coube a Sr. K2 (pai do cedente) determinados bens e valores, passando ele a ser o proprietário e titular de direitos sobre tais legados. Com a morte de Sr. K2 - em 1968 -, transferiu-se para Sr. Z (cedente) tais bens, mas como herança de seu pai, não de Sr. K, conforme demonstração gráfica a seguir:

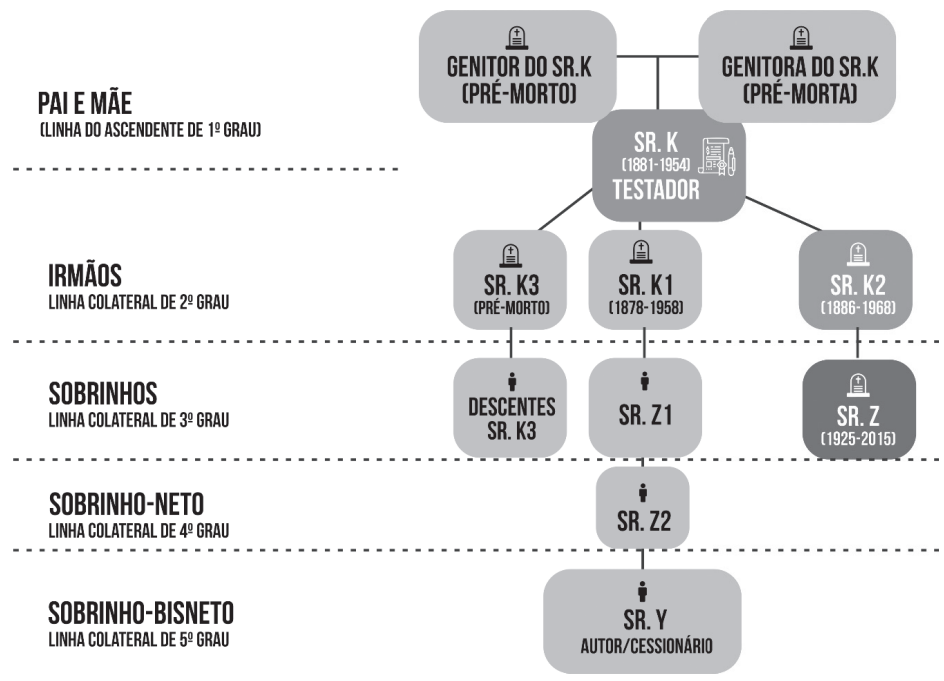


Assim, a cessão de direitos hereditários protagonizada por Sr. Z apenas seria viável se tivesse por objeto os seus direitos sucessórios em relação a seu pai, Sr. K2, o que não é o caso. Outrossim, reitera-se que, igualmente, deveria ser observado o momento da realização da cessão, como expresso no tópico anterior.

A despeito do declarado no documento em análise, Sr. Z jamais foi herdeiro ou legatário de Sr. K, motivo pelo qual carece de legitimidade para prática da cessão de direitos hereditários da forma como proposta. Assim, descumpre o disposto no art. 104, inc. I, do Código Civil de 2002, o que redunda na invalidade do negócio jurídico.

\subsubsection{Do objeto da cessão de direitos hereditários}

Entre os requisitos de validade do negócio jurídico está a necessidade de que o objeto seja possível. Essa possibilidade pode ser dar tanto no plano fático (possibilidade física), quanto no plano jurídico (possibilidade jurídica):

Objeto fisicamente impossível é o que, por sua própria natureza, não pode integrar qualquer relação jurídica. Objeto juridicamente impossível, o bem ou a prestação sobre os quais não permite a lei que os particulares transacionem, como as coisas que estão fora do comércio ou os atos contrários à moral e aos bons costumes. Na impossibilidade jurídica compreendem-se as coisas ou prestações que não se prestam a ser objeto do negócio ou de certo negócio. ${ }^{44}$ (Grifos no original)

No caso em análise, a impossibilidade do objeto se dá, sobretudo, sob dois aspectos.

Num primeiro momento, de acordo com o observado no tópico anterior (4.1.2), Sr. Z jamais foi herdeiro legítimo (ou necessário), tampouco legatário de Sr. K, de modo que não Ihe cabe qualquer direito hereditário (seja herança, seja legado). Assim, não poderia o cedente realizar qualquer tipo de transação sobre tais direitos, porquanto não the pertencem. Logo, a impossibilidade do objeto reside na impossibilidade de o sujeito alienar, ceder ou transacionar de qualquer forma bem ou direito de terceiro, que não Ihe pertence. ${ }^{45}$

GOMES, Orlando. Introdução ao direito civil. 22. ed. Rio de Janeiro: Forense, 2019. p. 266.

45 Notam-se manifestações nesse sentido na jurisprudência nacional: “COMPRA E VENDA DE IMÓVEL. TERRENO DE PROPRIEDADE DE TERCEIRO. NULIDADE DO NEGÓCIO JURÍDICO. OBJETO IMPOSSÍVEL. ART. 166, II, DO CC. [...] há bojo probatório suficiente a demonstrar a comercialização indevida de imóvel que não pertencia ao réu. Sendo certo que é nulo o negócio jurídico quando for impossível o seu objeto (art. 166, II, do CC), é medida de rigor a anulação do contrato de mov. 1.3, retornando-se ao status quo cabendo condenação ao 
De outra banda, conforme já observado (tópico 4.1.1), após adjudicados os bens do espólio pelos legatários, não há falar em direitos sucessórios, posto que eventuais bens e direitos transmitidos aos sucessores passam a compor a sua órbita patrimonial. Logo, qualquer negócio jurídico a partir desse momento terá caráter de compra e venda ou doação, sendo impossível ter como objeto direitos hereditários da forma realizada na "escritura pública declaratória de cessão de direitos hereditários", o que enseja a nulidade do ato, nos termos do art. 166, II do Código Civil de 2002. ${ }^{46}$

Outrossim, ainda que o documento de cessão de direitos hereditários cumprisse os requisitos, vale atentar para as limitações que tal negócio possui em relação ao seu objeto.

Nos termos do art. 1.793, §1ํㅡㄹ, do Código Civil de 2002, "os direitos, conferidos ao herdeiro em consequência de substituição ou de direito de acrescer, presumem-se não abrangidos pela cessão feita anteriormente". A partir dessa regra, se porventura algum herdeiro vier a renunciar à herança ou se ocorrer, por qualquer motivo, uma sobrepartilha, por exemplo, esses valores não serão incluídos na cessão já realizada.

É bem de ver que o objeto da cessão de direitos hereditários se limita à integralidade do quinhão do cedente ao tempo da realização do negócio, excluindo-se dele quaisquer valores supervenientes. Nas palavras de Gustavo Tepedino, Ana Luiza Nevares e Rose Meireles:

a cessão da herança se restringe ao quinhão de que dispunha o cedente no momento da celebração do contrato. Dessa forma, na hipótese de o quinhão aumentar por motivo superveniente, o acréscimo pertencerá ao cedente que, afinal, não perde a qualidade de herdeiro. ${ }^{47}$

Em complemento, vale a lição doutrinária de Rolf Madaleno:

A cessão de direitos hereditários agrega unicamente os bens existentes no momento da cessão, não incluindo os que sobrevierem

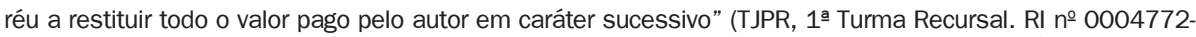
74.2017.8.16.0103. Rel. Juíza Melissa de Azevedo Olivas, j. 15.5.2019); “NULIDADE DO NEGÓCIO JURÍDICO POR IMPOSSIBILIDADE DO OBJETO - ART. 166, II DO CC. [...] O negócio jurídico (desfazimento do contrato) é nulo, tendo em vista a impossibilidade de o réu Benjamin transferir a propriedade do imóvel (Av. Parada Pinto), por não ser o proprietário (arts. 104 e 166, II, Código Civil) [...]" (TJSP, 2 ${ }^{\text {a }}$ Câmara Reservada de Direito Empresarial. Ap. Cív. no 1097238-08.2014.8.26.0100. Rel. Sérgio Shimura, j. 24.11.2020).

46 Art. 166 do Código Civil de 2002: “É nulo o negócio jurídico quando: [...] II - for ilícito, impossível ou indeterminável o seu objeto".

47 TEPEDINO, Gustavo; NEVARES, Ana Luiza Maia; MEIRELES, Rose Melo Vencelau. Fundamentos do direito civil: direito das sucessões. 2. ed. Rio de Janeiro: Forense, 2021. p. 38. 
por direito de acrescer ou por substituição (CC, art. 1.793, $\S 1^{\circ}$ ) . Isso porque o cedente não negocia sua condição de herdeiro, cujo direito é personalíssimo e intransferível, mas tão só transmite a fração da universalidade que lhe pertence no momento da cessão. ${ }^{48}$

Extrai-se das lições citadas outra característica da cessão de direitos hereditários: seu objeto restringe-se aos aspectos patrimoniais da herança, nunca ao título de herdeiro. Sobre o ponto, ensinam Cristiano Chaves de Farias e Nelson Rosenvald:

É importante frisar que o objeto da cessão de direitos hereditários não é, e não pode ser, a qualidade de herdeiro. Esta tem natureza personalíssima, sendo reconhecida pelo art. 5ำ, XXX, da Lex Legum, como um direito fundamental, sendo, por conseguinte, intransmissível.

O objeto da cessão de direitos hereditários é, tão só, o direito sobre o patrimônio que se transmitiu por conta da morte. Trata-se, pois, de uma transmissão de direitos econômicos, patrimoniais. ${ }^{49}$

Conclui-se: “A cessão de direitos hereditários só cede bens hereditários e não a condição de herdeiro, ou seja, o contrato de cessão não vende nem transfere a qualidade de herdeiro do cedente, que é incessível e fica fora do objeto alienado".50

No caso em análise, as observações supracitadas ganham relevo se, a despeito do todo aqui exposto acerca da nulidade do negócio jurídico, se entenda como válida e eficaz a escritura pública juntada do autor, senão vejamos.

Se porventura a revogação pretendida pelo autor tenha sucesso, os bens antes legados retornam ao monte e devem ser partilhados entre os herdeiros legítimos, conforme ordem de vocação hereditária, obedecido o regramento do Código Civil de 1916. Como examinado, a cessão de direitos hereditários realizada em 2011 não terá o condão de alcançar tais valores, pois se restringe ao patrimônio existente na data de sua lavratura. Ainda, tendo em vista que a qualidade de

48 MADALENO, Rolf. Sucessão legítima. 2. ed. Rio de Janeiro: Forense, 2020. p. 159.

49 FARIAS, Cristiano Chaves de; ROSENVALD, Nelson. Curso de direito civil: sucessões. 7. ed. Salvador: JusPodivm, 2021. p. 217.

50 MADALENO, Rolf. Sucessão legítima. 2. ed. Rio de Janeiro: Forense, 2020. p. 152. Complementa o autor: “[...] com o contrato de cessão de direitos hereditários não há transferência de um bem ou de determinados bens particulares, já que desde a aceitação da herança e até a efetivação da partilha o herdeiro é titular de uma quota que, por se encontrar ainda indivisa, não lhe atribui bens e direitos concretos, como tampouco o cessionário adquire a qualidade de herdeiro com a cessão de herança, pois esta é uma qualidade personalíssima que não se transmite com o contrato de cessão de direitos hereditários" (p. 86). 
herdeiro não é transmissível, o autor não possui legitimidade para requerer a revogação do legado nos termos como o fez, porquanto tal direito é reservado apenas aos herdeiros.

Essas questões aqui levantadas são analisadas com maior profundidade no tópico 4.2 deste parecer.

\subsubsection{Conclusão parcial: do não atendimento aos requisitos de validade do negócio jurídico}

Para responder ao primeiro quesito formulado, realizou-se a análise do documento intitulado "Escritura Pública Declaratória de Cessão de Direitos Hereditários" ${ }^{51}$ e, conforme o apresentado, percebe-se que:

a) o documento apresentado não atende à forma legal exigida para a cessão de direitos hereditários, uma vez que, embora tenha sido realizado por meio de escritura pública, o Provimento Conjunto no 93/2020 traz uma série de exigências quanto às informações que devem constar na referida escritura, não atendidas, no caso. Assim, descumpre o disposto no art. 104, inc. III, do Código Civil de 2002, o que, conforme o art. 166, inc. IV, ${ }^{52}$ do mesmo diploma, redunda na nulidade do negócio jurídico;

b) o cedente jamais foi herdeiro ou legatário do Sr. K, motivo pelo qual carece de legitimidade para prática da cessão de direitos hereditários da forma como proposta. Assim, descumpre o disposto no art. 104, inc. I, do Código Civil de 2002, o que redunda na invalidade do negócio jurídico;

c) o objeto da cessão de direitos hereditários apresentada é impossivel, porquanto não pertence ao cedente (ou seja, trata-se de negócio jurídico realizado sobre bem/direito de terceiro), bem como findo o inventário e adjudicação dos bens de Sr. K pelos legatários, há cerca de 44 anos antes da lavratura do documento, não há falar em direitos hereditários. Assim, descumpre o disposto no art. 104, inc. II, do Código Civil de 2002 o que, conforme o art. 166, inc. II, do mesmo diploma, redunda na nulidade do negócio jurídico.

Conclui-se, então, que a cessão de direitos hereditários apresentada pelo autor é um negócio jurídico nulo, porquanto não atende à forma prescrita em lei,

51 Documento juntado aos autos.

52 Art. 166 do Código Civil de 2002: “É nulo o negócio jurídico quando: [...] IV - não revestir a forma prescrita em lei". 
além de possuir objeto impossível. Não obstante, a incapacidade do cedente, consubstanciada pela sua ilegitimidade no caso, enseja a invalidade do negócio jurídico.

\subsection{Da legitimidade ad causam para revogação da deixa testamentária}

A ação em análise tem como pedido principal, em apertadíssima síntese, a revogação do legado instituído em favor da consulente pelo testamento do Sr. K, em razão do suposto descumprimento do encargo estipulado na deixa testamentária.

Note-se que, nos termos do art. 1.938 do Código Civil de 2002,53 "nos legados com encargo, aplica-se o disposto neste Código quanto às doações de igual natureza". Diante disso, a análise deste tópico tomará em consideração as regras atinentes à doação com encargo e as formas de revogação dessa espécie, fazendo também, sempre que necessário, o devido cotejo com a previsão do Código Civil de 1916.

Partindo dessa regra, o art. 560 do Código Civil de 2002 determina que "o direito de revogar a doação não se transmite aos herdeiros do doador, nem prejudica os do donatário. Mas aqueles podem prosseguir na ação iniciada pelo doador, continuando-a contra os herdeiros do donatário, se este falecer depois de ajuizada a lide". ${ }^{54}$

Perquirindo-se a ideia por trás desse regramento, pode-se concluir que o caráter personalíssimo da ação de revogação de doação se dá pela consequência de sua procedência. Isso porque, caso seja acolhido o pleito do autor (doador), o bem ou valor doado voltará a compor sua esfera patrimonial, restabelecendo o status quo.

Analisando a normativa da doação no âmbito da disposição testamentária, objeto da consulta, tem-se uma evidente dificuldade: sendo o testamento um instrumento jurídico de eficácia post mortem, como harmonizá-lo com esse caráter personalíssimo da ação de revogação? Estando o testador morto ao momento do cumprimento do encargo, quem seria legitimado ativo para a referida ação?

53 o Código Civil de 1916 trazia a mesma regra no art. 1.707: “ao legatário, nos legados com encargo, se aplica o disposto no artigo 1.180".

54 Previsão no mesmo sentido trazia o Código Civil de 1916, sem seu art. 1.185: "O direito de que trata o artigo precedente não se transmite aos herdeiros do doador, nem prejudica os do donatário. Mas aqueles podem prosseguir na ação iniciada pelo doador, continuando-a contra os herdeiros do donatário, se este falecer depois de contestada a lide". 
A resposta passa, justamente, pela reflexão já posta acerca dos efeitos patrimoniais da procedência do pedido de revogação. Não há dúvidas sobre a licitude da deixa testamentária com encargo, cabendo então verificar qual o destino deste legado acaso fosse revogada a disposição em razão do descumprimento do encargo.

Vale-se, para tanto, do conceito de caducidade no testamento, entendida como "a perda da eficácia de uma cláusula testamentária, por motivo ulterior, superveniente, à declaração de última vontade". ${ }^{55} \mathrm{~A}$ caducidade pode atingir o testamento como um todo (total) ou apenas uma ou algumas de suas cláusulas (parcial).

Como bem ensina Luiz Paulo Vieira de Carvalho, "caducar significa cair por terra, deixar de produzir efeitos, sem que haja declaração ou manifestação de vontade do testador nesse sentido, senão por circunstâncias de fato a que a lei atribui tais consequências". ${ }^{56}$ No caso em tela, à míngua de uma legislação específica para os legados com encargo, utilizando-se para análise o regramento da doação, como já referido, tem-se no descumprimento do encargo a base legal para caducidade de deixa testamentária como a aqui proposta. ${ }^{57}$

Com a caducidade, "torna-se ineficaz o testamento, aplicando-se à sucessão as regras da devolução sucessória legal, pelas quais são chamados os herdeiros legítimos" ${ }^{58}$ Ou seja, "a caducidade das disposições, abrangendo todos os herdeiros e legatários, transforma a sucessão de testamentária em legítima”.59 60

Postas essas reflexões, é crível concluir que a legitimidade ad causam para revogação de deixa testamentária por descumprimento do encargo estabelecido é dos herdeiros legítimos do testador, no caso, de Sr. K. Além disso, pode-se

55 FARIAS, Cristiano Chaves de; ROSENVALD, Nelson. Curso de direito civil: sucessões. 7. ed. Salvador: JusPodivm, 2021. p. 523.

56 CARVALHO, Luiz Paulo Vieira de. Direito das sucessões. São Paulo: Atlas, 2014.

57 Vale ressaltar que Orlando Gomes indica que "os casos de caducidade, reunidos numa só disposição, ocorrem, quanto às disposições testamentárias, nas seguintes circunstâncias de fato: [...] d) se não se realiza a condição aposta à instituição de herdeiro ou nomeação de legatário". Cf. GOMES, Orlando. Sucessões. 17. ed. Rio de Janeiro: Forense, 2019. p. 190.

58 GOMES, Orlando. Sucessões. 17. ed. Rio de Janeiro: Forense, 2019. p. 190.

59 PEREIRA, Caio Mário da Silva. Instituições de direito civil: direitos das sucessões. 27. ed. Rio de Janeiro: Forense, 2020. p. 363.

60 Nesse sentido é a jurisprudência: “[...] Em razão da caducidade do testamento no que toca à parte da herdeira pré-morta, e de não ter se configurado o direito de acrescer entre os demais herdeiros testamentários, tampouco existir previsão de substituição, tem-se que a quota vaga retorna ao monte mor, devendo ser transmitida aos outros sucessores segundo as normas da sucessão legítima, nos termos que enuncia o art. 1.944, caput, do Código Civil. [...]" (TJGO, 5a Câmara Cível. Ag. Inst. ㄲo 02242446820188090000. Rel. Camila Nina Erbetta Nascimento e Moura, j. 27.5.2019); “[...] Tendo o legatário falecido anteriormente ao testador, resta configurada a caducidade do testamento, devendo ser observada a ordem de vocação hereditária, nos termos do artigo 1829 do Código Civil. [...]" (TJMG, 5’ Câmara Cível. Ap. Cív. № 10342140038767001, Rel. Versiani Penna, j. 7.5.2015). 
considerar o testamenteiro como legitimado, uma vez que é inerente à sua função zelar pelo cumprimento das disposições testamentárias. ${ }^{61}$

Nesse cenário vislumbra-se que especialmente a legitimidade dos herdeiros para pleitear a revogação do legado se funda, também, no interesse de agir, requisito processual que deve ser atendido para o regular processamento da demanda em juízo. Como ensina Fredie Didier Júnior, “o interesse de agir é um requisito processual extrínseco positivo: é fato que deve existir para que a instauração do processo se dê validamente. Se por acaso faltar interesse de agir, o pedido não será examinado".62

De acordo com o autor, o interesse de agir dever ser examinado em duas dimensões: necessidade e utilidade da tutela jurisdicional. Em relação ao exame “da 'necessidade da jurisdição', fundamenta-se na premissa de que a jurisdição tem de ser encarada como última forma de solução de conflitos". ${ }^{63}$ De outra banda, "há utilidade sempre que o processo puder propiciar ao demandante o resultado favorável pretendido; sempre que o processo puder resultar em algum proveito ao demandante". ${ }^{64}$

Pode-se dizer, conforme lição de José Carlos Barbosa Moreira, que o provimento judicial será útil sempre que “por sua natureza, verdadeiramente se revele - sempre em tese - apta a tutelar, de maneira tão completa quanto possível, a situação jurídica do requerente". ${ }^{65}$ No mesmo sentido e complementando a ideia, Cândido Rangel Dinamarco explica:

Sem antever no provimento pretendido a capacidade de oferecer essa espécie de vantagem a quem o postula, nega-se a ordem jurídica a emiti-lo e, mais que isso, nega-se a desenvolver aquelas atividades ordinariamente predispostas à sua emissão (processo, procedimento, atividade jurisdicional). ${ }^{66}$

Assim, em vista do proveito que os herdeiros legítimos obteriam com a revogação do legado instituído em testamento, mormente quando fundada no

61 Nos termos do art. 1.981 do Código Civil de 2002: “compete ao testamenteiro, com ou sem o concurso do inventariante e dos herdeiros instituídos, defender a validade do testamento". Norma prevista também no art. 1.760 do Código Civil de 1916.

62 DIDIER JÚNIOR, Fredie. Curso de direito processual civil: introdução ao direito processual civil, parte geral e processo de conhecimento. 22. ed. Salvador: JusPodivm, 2020. p. 458.

63 DIDIER JÚNIOR, Fredie. Curso de direito processual civil: introdução ao direito processual civil, parte geral e processo de conhecimento. 22. ed. Salvador: JusPodivm, 2020. p. 460.

64 DIDIER JÚNIOR, Fredie. Curso de direito processual civil: introdução ao direito processual civil, parte geral e processo de conhecimento. 22. ed. Salvador: JusPodivm, 2020. p. 459.

65 MOREIRA, José Carlos Barbosa. Ação declaratória e interesse. Direito processual civil (ensaios e pareceres). Rio de Janeiro: Borsoi, 1971. p. 17.

66 DINAMARCO, Cândido Rangel. Execução civil. 7. ed. São Paulo: Malheiros, 2000. p. 402. 
descumprimento de encargo, fica clara a sua legitimidade em tal pleito, ainda porque justificada pela necessidade e utilidade inerentes ao interesse de agir no processo judicial.

Postas essas premissas, percebe-se que o autor da demanda, Sr. Z, não figura entre os legitimados para propositura da ação intentada, senão vejamos.

Veja-se que o testador indicou como testamenteiro o advogado Dr. B, ${ }^{67}$ cargo que é indelegável e intransmissível,68 além de já ter sido integralmente cumprido por oportunidade do inventário do testador e adjudicação dos bens pelos legatários.

Excluindo-se a possibilidade de o autor figurar como testamenteiro, passa-se à análise da sua classificação ou não como herdeiro legítimo, o que remonta às conclusões colhidas no tópico preliminar deste parecer (tópico 3). Com efeito, a análise antes realizada conclui que Sr. Z (autor) é parente colateral de 5o grau de Sr. K (testador/autor da herança).

Ainda conforme o já exposto, na vigência do Código Civil de 1916 (aplicável ao tempo da abertura da sucessão), em que pese o parentesco colateral fosse até o 6ำ grau, a linha sucessória dos colaterais restringia-se ao 4ำ grau. ${ }^{69}$ Ainda, caso se entenda aplicável à eventual partilha do legado revogado o Código Civil de 2002 (vigente ao tempo da revogação), mais restrita ainda é a linha de parentesco colateral, que contemporaneamente se limita ao $4^{\circ}$ grau. $^{70}$

Nesse cenário, em caso de procedência do pleito revogatório, o legado objeto da ação seria partilhável pelos herdeiros de Sr. K, sendo esses os considerados ao tempo de seu óbito, limitando-se aos colaterais de até $4^{\circ}$ grau. 0 autor, repisa-se, por ser parente colateral de $5^{\text {}}$ grau, jamais seria considerado herdeiro legítimo, ainda porque sequer era nascido ao tempo da abertura da sucessão. ${ }^{71}$

Nem se cogita eventual direito sucessório do autor advindo da "escritura pública declaratória de cessão de direitos hereditários", como amplamente demonstrado no tópico anterior: seja porque o referido documento não atende a nenhum dos requisitos de validade do negócio jurídico, sendo, portanto, nulo; seja porque o título de herdeiro possui caráter personalíssimo e não pode ser objeto de cessão.

67 Conforme indicação no testamento.

68 Conforme determina o art. 1.985 do Código Civil de 2002: “O encargo da testamentaria não se transmite aos herdeiros do testamenteiro, nem é delegável; mas o testamenteiro pode fazer-se representar em juízo e fora dele, mediante mandatário com poderes especiais". Norma prevista também no art. 1.764 do Código Civil de 1916, com a seguinte redação: "O encargo da testamentaria não se transmite aos herdeiros do testamenteiro, nem é delegável. Mas o testamenteiro pode fazer-se representar em juízo e fora dele, mediante procurador com poderes especiais".

69 Conforme os já transcritos arts. 331 e 1.612 do Código Civil de 1916.

70 Conforme os já transcritos arts. 1.592 e 1.839 do Código Civil de 2002.

71 Em que pese o Código Civil de 1916 seja silente quanto a esse aspecto, o art. 1.798 do Código Civil de 2002 dispõe que "legitimam-se a suceder as pessoas nascidas ou já concebidas no momento da abertura da sucessão". 
Feitas tais considerações à luz do quesito proposto, conclui-se que o autor da demanda, Sr. Z, não possui legitimidade ativa para propositura da ação que busca a revogação da liberalidade testamentária por descumprimento de encargo, visto que não pode ser considerado herdeiro legítimo ou testamenteiro do autor da herança, o que implica também a ausência de interesse de agir em juízo.

\section{3 Dos encargos impostos ao legado em favor da XXX}

Depreende-se da leitura do testamento do Sr. K que ao legado instituído em favor da XXX foram impostos dois encargos (indicados como "condições" pelo testador na cédula), ${ }^{72}$ quais sejam:

i) "manter e conservar, sem modificar ou transformar, a sede ora doada, cuidando dela como patrimônio histórico da cidade [...], das famílias $[\ldots] "$;

ii) "manter um serviço de assistências às crianças desamparadas e aos veIhos doentes, com o produto da venda dos terrenos fora dos muros que cercam os pátios da sede, sendo estes pátios considerados inalienáveis, assim como é considerada inalienável a referida sede, que mede 100 (cem) metros de frente até a divisa dos fundos. O restante da "Fazenda", constante de terrenos em pasto, a XXX ou a instituição escolhida a critério de meus irmãos, Sr. K1 e Sr. K2, poderá do mesmo dispor como entender, porém sempre em benefício da própria instituição".

O pleito principal da ação intentada por Sr. Z (demandante) em desfavor da XXX (demandada/consulente) trata-se, como já visto, da revogação de tal legado fundado no descumprimento dos encargos. Por essa razão, o quesito proposto busca estabelecer se é possível considerar o encargo em comento como devidamente cumprido e, ainda, se há possibilidade de o legatário exonerar-se desses encargos.

Novamente, à luz do art. 1.938 do Código Civil de 2002 e do art. 1.707 do Código Civil de 1916, utiliza-se o regramento das doações com encargo para a análise proposta, além das normas próprias da interpretação do testamento, reiterando o cotejo entre as disposições do diploma civil vigente e do revogado, sempre que pertinente.

72 Conforme testamento. 


\subsubsection{Da interpretação das disposições testamentárias e dos negócios jurídicos}

Antes de adentrar especificamente na resposta ao quesito proposto, é importante traçar algumas diretrizes acerca da interpretação das disposições testamentárias e dos negócios jurídicos. ${ }^{73}$ Nessas premissas baseia-se toda a análise da consulta posta, sobretudo em relação ao encargo estipulado à legatária.

Nos termos do art. 1.899 do Código Civil de 2002, "quando a cláusula testamentária for suscetível de interpretações diferentes, prevalecerá a que melhor assegure a observância da vontade do testador". ${ }^{74}$

O que se percebe é que o problema da interpretação das cláusulas testamentárias concerne a outro ainda mais genérico, qual seja, da própria efetivação do testamento. ${ }^{75}$ Sobre o tema, na lição de Zeno Veloso, "cabe ao intérprete analisar, investigar, pesquisar, mas com o intuito e objetivo de descobrir e revelar a real vontade, a vera intenção do testador". ${ }^{76}$ Nas palavras de Luiz Paulo Vieira de Carvalho:

A função do intérprete, então, que se faz através dos diferentes modos de interpretação, quais sejam, filológico, histórico, lógico, sistemático e teleológico, é aclarar as verdadeiras intenções do autor do ato de última vontade, buscando, sempre, a realidade dos efeitos por esse pretendidos (princípio da preponderância da vontade do testador), efeitos a serem cumpridos desde que não ofendam a ordem pública, é claro. ${ }^{77}$

Essa lógica é trazida também pelo art. 112 do Código Civil de 2002,78 ao dispor que "nas declarações de vontade se atenderá mais à intenção nelas consubstanciada do que ao sentido literal da linguagem". À luz desse dispositivo, "o que importa é a vontade real e não a vontade declarada, importando interpretar o negócio, de acordo com a boa-fé, para elucidar a intenção das partes, sem vinculação ao teor da redação do negócio (linguística)" ${ }^{79}$

73 Isso porque, conforme defendido doutrinariamente, “o testamento é negócio jurídico gratuito e mortis causa vez que não tem por objetivo a obtenção de vantagens ao testador, por tratar-se de disposição post mortem, sua eficácia somente ocorrerá após a abertura da sucessão". Cf. ROSA, Conrado Paulino da; RODRIGUES, Marco Antonio. Inventário e partilha. 3. ed. Salvador: JusPodivm, 2021. p. 243.

74 Norma constante também no art. 1.666 do Código Civil de 1916, com idêntica redação.

75 FARIAS, Cristiano Chaves de; ROSENVALD, Nelson. Curso de direito civil: sucessões. 7. ed. Salvador: JusPodivm, 2021. p. 692.

76 VELOSO, Zeno. Comentário ao Código Civil. São Paulo: Saraiva, 2003. p. 210.

77 CARVALHO, Luiz Paulo Vieira de. Direito das sucessões. 4. ed. São Paulo: Atlas, 2019. p. 713.

78 Sem correspondente no Código Civil de 1916.

79 FARIAS, Cristiano Chaves de; ROSENVALD, Nelson. Curso de direito civil: sucessões. 7. ed. Salvador: JusPodivm, 2021. p. 692. 
De acordo com Cristiano Chaves de Farias e Nelson Rosenvald, trata-se da chamada teoria da confiança, que mantém íntima relação com o princípio da boa-fé objetiva. Conforme os autores, "por conta da teoria da confiança, a declaração de vontade deve prevalecer sobre a efetiva vontade na medida em que tenha suscitado legítima expectativa no destinatário, conforme as circunstâncias objetivas". ${ }^{80}$

A boa-fé na interpretação dos negócios jurídicos, por sua vez, vem encartada no art. 113 do Código Civil de 2002,81 ao dispor que "os negócios jurídicos devem ser interpretados conforme a boa-fé e os usos do lugar de sua celebração". Ainda na linha de pensamento dos autores supracitados, “a boa-fé objetiva é a busca do equilíbrio", e complementam:

Constitui-se, a um só tempo, na estipulação de deveres anexos, implícitos, nos negócios, impondo probidade, honestidade, ética, honradez e informação, mesmo não estando previstos expressamente na declaração negocial, além de limitar o exercício dos direitos subjetivos, evitando o abuso de direito e, finalmente, servindo como fonte de interpretação dos negócios jurídicos. ${ }^{82}$

Aplicando essas reflexões à interpretação das disposições testamentárias, deve-se ter em mente não apenas a máxima efetividade da vontade do testador, como também a proteção dos herdeiros e legatários por ele instituídos, sob o prisma da boa-fé e da confiança. Essa também é a conclusão de Luiz Paulo Vieira de Carvalho:

Por outro lado, o testamento deve ser objeto de análise e direção também como instrumento de proteção dos herdeiros, caso haja instituição dos mesmos, e dos eventuais legatários, que, embora não sejam beneficiados pela saisina, se a vontade do testador foi a de protegê-los, contemplando-os a título singular, deverá ser respeitada, até porque, ao testar e contemplar sucessores, o disponente exerce o seu direito de propriedade para o futuro, em decorrência de ter amealhado patrimônio em vida, no mais dos casos, por merecido esforço próprio. ${ }^{83}$

80 FARIAS, Cristiano Chaves de; ROSENVALD, Nelson. Curso de direito civil: parte geral e LINDB. 19. ed. Salvador: JusPodivm, 2021. p. 692.

81 Sem correspondente no Código Civil de 1916.

82 FARIAS, Cristiano Chaves de; ROSENVALD, Nelson. Curso de direito civil: parte geral e LINDB. 19. ed. Salvador: JusPodivm, 2021. p. 689.

83 CARVAlHO, Luiz Paulo Vieira de. Direito das sucessões. 4. ed. São Paulo: Atlas, 2019. p. 714. 
Partindo dessas premissas é que se realiza, no tópico seguinte, a análise especificamente da deixa testamentária em favor de XXX, mormente a intenção do testador na instituição dos encargos. Busca-se, conforme o explanado, harmonizar a realização do desejo do testador e a proteção dos legatários, sempre pautado na boa-fé e confiança que devem reger as relações jurídicas.

\subsubsection{Do cumprimento dos encargos pela legatária e da impossibilidade de manutenção perpétua do encargo}

Inicialmente, pode-se conceituar encargo como "a determinação pela qual se impõe um ônus, uma obrigação, ao beneficiário de um ato gratuito, de uma liberalidade. [...] Enfim, é uma contraprestação imposta ao beneficiário de um negócio jurídico gratuito". ${ }^{84}$ Outrossim,

diversamente do termo ou da condição, salvo ressalva expressa, o encargo não suspende a aquisição ou o exercício do direito (CC, art. 136). Assim, a imposição de um encargo em uma doação não afetará a validade ou a eficácia, apenas permitirá a sua exigibilidade jurídica. ${ }^{85}$

Por tal razão, não há qualquer dúvida sobre a validade e eficácia da deixa testamentária, sobretudo porquanto a propriedade em favor da legatária XXX foi devidamente registrada em 1969, após realização do inventário do testador, conforme demonstram os documentos dos autos. Não obstante, dada a possibilidade de exigência do encargo pelos interessados, cumpre agora examinar o limite de tal ônus à legatária.

Novamente, remonta-se à doação com encargo ou modal que pode ser conceituada como "aquela em que se impõe ao donatário uma carga ou um gravame de valor inferior ao do bem doado". ${ }^{86}$ Logo, "doação modal é o negócio jurídico por força do qual o doador, animado por liberalidade, transmite uma coisa ao donatário, deste exigindo, para a eficácia do contrato, a realização de uma obrigação de valor inferior ao da coisa transmitida" ${ }^{87}$

84 FARIAS, Cristiano Chaves de; ROSENVALD, Nelson. Curso de direito civil: parte geral e LINDB. 19. ed. Salvador: JusPodivm, 2021. p. 730.

85 FARIAS, Cristiano Chaves de; ROSENVALD, Nelson. Curso de direito civil: contratos. 8. ed. Salvador: JusPodivm, 2018. p. 808.

86 NERY JÚNIOR, Nelson. Doação e encargo. Soluções práticas de direito. Revista dos Tribunais, São Paulo, v. 7, p. 575-600, set. 2014.

87 MARQUESI, Roberto Wagner. A doação modal no Código Reale. Revista de Direito Privado, São Paulo, v. 42, p. 91-105, abr./jun. 2010. 
Ressalta das lições doutrinárias referidas uma importante observação: o encargo (seja ele da doação, seja ele do legado) não deve ultrapassar o valor ou o benefício resultante da própria liberalidade. Ou seja, o ônus do legatário em cumprir o encargo não pode superar o bônus que ele teria com o legado. Essa é a conclusão doutrinária de Nelson Nery Júnior acerca da doação com encargo, aplicável também aos legados:

O fato de doar alguém parte de seu patrimônio gratuitamente pode levar a entender que a imposição de encargo seja equivalente a uma contraprestação da parte do donatário, circunstância que desvirtuaria a doação. Assim não é. Subsiste a doação sempre que o encargo for de valor inferior ao da liberalidade. Quer isto significar que, feita a dedução do encargo, a parte que exceder em valor concorrerá para o enriquecimento do patrimônio do beneficiado. ${ }^{88}$

Com efeito, o que se percebe, analisando-se os encargos dos legados instituídos à XXX nos dias atuais, mormente quanto à manutenção da sede da "Fazenda", é que os custos para seu cumprimento sobrelevam consideravelmente os seus benefícios.

Há que se considerar que o custo estimado para manter a sede "sem modificar ou transformar [...] cuidando dela como patrimônio histórico da cidade [...]" nas décadas de 1950 e 1960, período em que lavrado o testamento e adjudicados os bens pelos legatários, era muito inferior ao atual. Acresce-se a isso o fato de que em 1990 o referido imóvel foi tombado pelo Poder Executivo Municipal, o que sabidamente requer mão de obra extremamente especializada para seus reparos.

Não obstante, conforme demonstrado nos autos, a legatária envidou todos os esforços para que fosse possível realizar tal encargo, chegando a investir $\mathrm{R} \$ 186.920,54$ em obras no local. Veja-se também que há projeto para restauração da sede da "Fazenda", realizado junto à Universidade Federal [...], mas que depende da aprovação e concessão de financiamento federal, o que escapa do controle da legatária.

Nota-se, então, no cenário exposto, que a interpretação literal e irrestrita da deixa testamentária, mormente do seu encargo no ponto, trará acentuado prejuízo à legatária, o que vai de encontro ao buscado pelo testador quando da instituição do legado e à proteção da XXX, que mantém em seu patrimônio durante todos esses anos a "Fazenda". Como já dito, a interpretação das disposições testamentárias deve sempre considerar a máxima vontade do testador, a proteção do

88 NERY JÚNIOR, Nelson. Doação e encargo. Soluções práticas de direito. Revista dos Tribunais, São Paulo, v. 7 , p. $575-600$, set. 2014 . 
herdeiro/legatário e a boa-fé, que não serão atendidos com a exigência de cumprimento do encargo nos termos em que postos pelo autor da demanda revogatória.

É bem de ver que caso o cumprimento do encargo seja mais custoso, em qualquer medida, que a vantagem do legatário obtida com o legado, subverte-se a própria natureza e intenção da deixa testamentária, como bem sinala a doutrina sobre o tema:

Todavia, se a doação clausulada por encargo é um contrato bilateral, nem por isso será sinalagmático. Obrigações para ambos existem, mas elas não se equivalem em termos econômicos. Se equivalência houver, não se terá doação, mas permuta ou compra e venda, v.g. A disparidade reside no fato de que o dever do donatário não constitui uma contraprestação, mas sim um fator restritivo da liberalidade. ${ }^{89}$

Por outro ponto vista, diga-se que no cenário apresentado é possível entender a manutenção contemporânea da sede da "Fazenda", nos termos determinados, como um encargo impossível. Assim, tem-se como não escrito, conforme clássica lição de Orosimbo Nonato:

Assim, quando a um ato jurídico... se aponha uma condição suspensiva impossível fisicamente, de modo objetivo, ou absolutamente inexequível pela pessoa que tenha de realiza-la, a condição se considera inexistente, o ato prevalece como puro e incondicionado. Se, ao invés, houver qualquer possibilidade de satisfazê-la a pessoa considerada, muito embora se Ihe ofereça dificuldade séria, vale a condição que produzirá os respectivos efeitos, impedindo que se adquira o direito, enquanto se não verificar. ${ }^{90}$

No mesmo sentido é a doutrina de Pontes de Miranda:

Condições fisicamente impossiveis. Entende a lei brasileira separar as duas impossibilidades: a física, e a jurídica. Tratá-las diferentemente: aquela vitiatur, non vitiat; esta, vitiatur, et vitiat.

Pra bem apanharmos o campo de aplicação do art. 116, 1ํㅗㄹ parte, em que se reputa inexistente a condição fisicamente impossivel, quer dizer - não escrita (vicia-se, mas não vicia). ${ }^{91}$

89 MARQUESI, Roberto Wagner. A doação modal no Código Reale. Revista de Direito Privado, São Paulo, v. 42, p. 91-105, abr./jun. 2010.

90 NONATO, Orosimbo. Estudos sobre sucessão testamentária. Rio de Janeiro: Forense, 1957. v. II. p. 292.

91 PONTES DE MIRANDA, Francisco Cavalcanti. Tratado dos testamentos. Atualização de Vilson Rodrigues Alves.

1. ed. Leme: BH, 2005. v. III. p. 91-92. 
Vale atentar ainda para as consequências do inadimplemento do encargo sem culpa do legatário, o que enseja o entender como cumprido, conforme doutrina do tema:

E se o inadimplemento não for culposo?

Nos contratos bilaterais, quando o inadimplemento da obrigação se impossibilita para uma das partes, sem que haja culpa, a obrigação se resolve para ambas, porque, de outro modo, a que pudesse cumprir ficaria em desvantagem, pela ausência de contraprestação (Cód. Civ., arts. 865, 869, $1^{\text {a }}$ parte e 872 ).

Todavia, e embora a doação seja contrato oneroso na parte em que há encargo, a solução não é essa.

Com efeito, se o inadimplemento não fôr culposo, o donatário escusa-se da sua obrigação, pelo força maior e nem por isso a doação se resolve. ${ }^{92}$

Outra característica da estipulação do encargo na doação, pertinente à deixa testamentária, é seu caráter restritivo em relação à disposição do patrimônio pelo legatário: "Sua presença [do encargo] na doação restringe a amplitude da liberalidade, mas não a desqualifica como tal, donde ser lícito concluir que o valor do encargo não pode atingir ou suplantar o valor da coisa doada. Se isso vier a ocorrer, desnaturada estará a liberalidade". ${ }^{93}$ Daí se conclui que a mesma lógica aplicada à interpretação das disposições testamentárias restritivas deve ser feita para os legados com encargo.

Por tal motivo, interessante se faz a análise do julgado do Superior Tribunal de Justiça definindo que "a cláusula de inalienabilidade vitalícia tem vigência enquanto viver o beneficiário, passando livres e desembaraçados aos seus herdeiros os bens objeto da restrição". ${ }^{94}$

Conforme a relatora, Ministra Nancy Andrighi:

[...] há que se atentar para o propósito da cláusula de inalienabilidade que é a proteção do patrimônio do beneficiário. A restrição, portanto, não pode ter vigência para além de sua vida. Com a sua morte, se não há a instituição de novo gravame por disposição testamentária, os bens se transmitem aos herdeiros de forma livre e desembaraçada.

92 ALVIM, Agostinho. Da doação. 2. ed. São Paulo: Saraiva, 1972. p. 264.

93 MARQUESI, Roberto Wagner. A doação modal no Código Reale. Revista de Direito Privado, São Paulo, v. 42, p. 91-105, abr./jun. 2010.

94 STJ, 3르. TEsp o 1.101.702/RS. Rel. Min. Nancy Andrighi, j. 22.9.2009. DJe, 9 out. 2009. 
A ministra também assentou seu voto no entendimento de Pontes de Miranda, ${ }^{95}$ além das lições de Silvio Rodrigues. ${ }^{96}$

Extrai-se desse julgamento a conclusão inarredável de que não se pode manter a cláusula restritiva testamentária eternamente, sendo ela vigente por apenas uma geração. Olhando para o caso em análise pelas lentes dessa decisão, percebe-se que a legatária XXX vem suportando a restrição ao seu legado por mais de 60 anos.

Por certo que não se pode aplicar o limite da morte, exposto no julgamento, ao presente caso, no qual a legatária é uma pessoa jurídica, mas se mostra inadequado não estabelecer qualquer limite temporal ao encargo. Desta forma, consoante abordado no tópico anterior, entende-se que o termo final da "geração" nos casos como este, em que não haja o falecimento do legatário, deve ser estipulado com razoabilidade à luz da boa-fé.

Vale aqui também outro entendimento do Superior Tribunal de Justiça, dessa vez sobre a possibilidade de mitigação das cláusulas restritivas em atenção à função social do bem. ${ }^{97} \mathrm{Na}$ oportunidade, a Corte foi instada a decidir se há possibilidade de cancelamento, em hipóteses excepcionais, das cláusulas de inalienabilidade, impenhorabilidade e incomunicabilidade vitalícias impostas em testamento.

A relatora, Ministra Nancy Andrighi, remonta à finalidade do legislador ao editar o art. 1.676 do Código Civil de 1916, ${ }^{98}$ que buscava proteger o patrimônio familiar e assegurar aos descendentes uma espécie de amparo financeiro ante as incertezas da vida econômica e social. Conforme lição de Clóvis Bevilaqua, citada no acórdão:

as cláusulas de inalienabilidade em testamento foram recepcionadas pelo ordenamento jurídico "para defender a inexperiência dos indivíduos, para assegurar o bem estar da família, para impedir a

95 Indicada no voto a obra PONTES DE MIRANDA, Francisco Cavalcanti. Tratado de direito privado. 3. ed. Rio de Janeiro: Borsoi, 1973. t. LVIII. p. 58.

96 O seguinte trecho da doutrina é transcrito no voto: “'A cláusula de inalienabilidade, entretanto, não excederá, me duração à vida do herdeiro, que tem livre disposição dos bens, por testamento, e, em falta deste, a sua livre transmissão aos sucessores legítimos. Em suma, a inalienabilidade não pode ser perpétua, não pode estender-se para além da vida do herdeiro' (Silvio Rodrigues. Direito Civil - Direito das Sucessões. Ed. Saraiva: São Paulo. 26a Edição, 2003, p. 129)".

97 STJ, 3a T. REsp no 1.158.679/MG. Rel. Min. Nancy Andrighi, j. 7.4.2011. DJe, 15 abr. 2011.

98 Nos termos do art. 1.676 do Código Civil de 1916: "A cláusula de inalienabilidade temporária, ou vitalícia, imposta aos bens pelos testadores ou doadores, não poderá, em caso algum, salvo os de expropriação por necessidade ou utilidade pública, e de execução por dívidas provenientes de impostos relativos aos respectivos imóveis, ser invalidada ou dispensada por atos judiciais de qualquer espécie, sob pena de nulidade". O Código Civil de 2002 traz nova redação, excluindo a impossibilidade de invalidação da cláusula restritiva: "A cláusula de inalienabilidade, imposta aos bens por ato de liberalidade, implica impenhorabilidade e incomunicabilidade". 
delapidação dos pródigos". Por essas razões, "o direito consente em que seja, temporariamente, entrevada a circulação de determinados bens". .9

A decisão do Superior Tribunal de Justiça, que permitiu a alienação de bem gravado por cláusula de inalienabilidade, partiu de um exercício hermenêutico do dispositivo legal, atribuindo-Ihe "um sentido tal que resulte haver a lei regulado a espécie a favor, e não em prejuízo de quem ela evidentemente visa a proteger”. ${ }^{100}$ Conclui a relatora que "se a manutenção das cláusulas de inalienabilidade, impenhorabilidade e incomunicabilidade instituídas em testamento acabam por constituir verdadeiros obstáculos à própria fruição do imóvel pelo proprietário, sua relativização não só é possível como é também necessária” e complementa:

Essa necessidade decorre do fato de que a supressão ao direito de livremente dispor dos bens - ainda que eficazmente instituída por meio de testamento válido - não pode ser considerada de modo absoluto, devendo ser delimitada por preceitos de ordem constitucional, como a função social da propriedade e a dignidade da pessoa humana. Não parece razoável admitir que a sobrevivência e o bem-estar da recorrida sejam prejudicados, em prol da obediência irrestrita às cláusulas de inalienabilidade, impenhorabilidade e incomunicabilidade. [...]

Os gravames, além do mais, devem sempre ter em vista a função social da propriedade sobre a qual foram impostos, pois não é possível admitir a manutenção de um bem que acabe por prejudicar seu proprietário, de modo a causar-lhe aflições e frustrações. O exercício do direito de propriedade, nesses casos, descaracteriza-se tanto jurídica quanto economicamente [...]. Daí decorre, ainda, que o impedimento ao exercício dos direitos decorrentes da propriedade por um longo período de tempo e na presença de circunstâncias que justifiquem a disposição do bem constitui ofensa ao princípio da função social da propriedade, já que impede a livre circulação e exploração da riqueza. [...]

Considero importante, ainda, aludir às normas do arts. 1.666 do CC/1916 (correspondente ao art. 1.899 do CC/02) e 85 do mesmo diploma legal (reproduzida pelo art. 112 do CC/02). Assim, o abrandamento das cláusulas de inalienabilidade, incomunicabilidade e impenhorabilidade, na hipótese dos autos, é a medida que melhor

99 Conforme citação no acórdão: BEVILAQUA, Clovis. Código Civil dos Estados Unidos do Brasil Commentado. Rio de Janeiro: Livraria Francisco Alves, 1919. v. VI. p. 128.

100 Trecho extraído da p. 8 do voto da relatora, citando MAXIMILIANO, Carlos. Hermenêutica e aplicação do direito. 17. ed. Rio de Janeiro: Forense, 1998. p. 156. 
atende à vontade do testador (art. 1.666 do CC/16). De fato, diante das peculiaridades dos fatos, é evidente que não se pode presumir a oposição da avó da recorrida ao pedido, se ainda fosse viva. A mesma conclusão advém da circunstância de que "nas declarações de vontade se atenderá mais à sua intenção que ao sentido literal da linguagem" (art. 85 do CC/16), sendo igualmente patente que o objetivo da testadora das cláusulas foi o favorecimento de sua neta, que atualmente se encontra em delicada situação financeira.

Analisando o presente caso por meio dos fundamentos assentados nesse julgado da Corte Superior, é de se concluir, mais uma vez, pela inaplicabilidade do encargo imposto à XXX, porquanto seu cumprimento da forma como expressa acaba por desnaturar a própria função do legado e da legatária, bem como a consequência esperada pelo testador.

Com efeito, depreende-se do encargo relativo à manutenção de "serviço de assistências às crianças desamparadas e aos velhos doentes", mormente por ter sido instituído o legado em favor da XXX, que tem em sua função precípua o auxílio social, que sua vontade era de perpetuar cuidados e assistência à sociedade da cidade $[. .$.$] .$

Nesse sentido, ainda que a legatária, atualmente, não tenha um programa específico para o atendimento de crianças e idosos, a sua atuação natural, como sabido, já traz notáveis benefícios à essa parcela da população. Veja-se que é missão de XXX proporcionar a todos os grupos sociais ações de saúde e bem-estar, de forma humanizada e agindo com misericórdia, além de manter uma série de serviços humanizados. Não obstante, depreende-se da documentação juntada aos autos que por muito tempo a legatária manteve, sim, projetos voltados especificamente para atendimento do encargo testamentário, inclusive por meio do "Instituto Sr. K", criado a partir de uma parceria entre a ela e outra associação com os mesmos fins. ${ }^{101}$

Além disso, em vista da realização, por décadas, de programas voltados ao público indicado no encargo testamentário, considerando também o todo aqui examinado, mormente em relação à interpretação do testamento e dos negócios jurídicos, notadamente à luz da boa-fé, bem como a impossibilidade de restrição ad aeternum em razão do encargo, é de se considerar a aplicação ao caso da teoria do adimplemento substancial. Acerca dessa teoria, interessante a doutrina de Cristiano Chaves de Farias e Nelson Rosenvald:

101 A discriminação dos programas realizados e seus objetivos, bem como da instituição parceira referida, foram suprimidos desta publicação a fim de manter o sigilo e a ética profissional. 


\begin{abstract}
A tese do inadimplemento mínimo é uma das formas de controle da boa-fé sobre a atuação de direitos subjetivos. Atualmente, é possível questionar a faculdade do exercício do direito potestativo à resolução contratual pelo credor, em situações caracterizadas pelo cumprimento de substancial parcela do contrato pelo devedor, mas em que, todavia, não tenha suportado adimplir uma pequena parte da obrigação. É que se apresenta abusivo o exercício de um direito pela parte que pretende ver resolvido um negócio jurídico somente porque a contraparte descumpriu, minimamente, as suas obrigações. É o abuso do direito à rescisão de um contrato, porque os drásticos efeitos que podem decorrer afrontam o senso ético das partes. ${ }^{102}$
\end{abstract}

Assim, tem-se que tal teoria reforça os demais argumentos aqui expostos no sentido de que se deve considerar totalmente cumpridos os encargos impostos ao legado aqui examinados.

Outrossim, não há falar em eventual irregularidade ou descumprimento por parte da legatária em razão da implementação do Cemitério [...], uma vez que, conforme consta no testamento do Sr. K, a legatária poderia dispor dos terrenos da "Fazenda" como entendesse, sempre em benefício da própria instituição.

Ainda, a manifestação expressa do testador de que os rendimentos auferidos a partir do legado deveriam ser empregados em benefício da própria instituição reforça a intenção da disposição no sentido de favorecer a legatária. Por isso, entende-se inadequada qualquer interpretação que incorra em acentuado ônus à XXX, sob pena de ferir a vontade do testador e subverter a lógica pretendida com o legado.

\title{
4.3.3 Conclusão parcial quanto ao ponto: do cumprimento dos encargos pela legatária
}

Para responder ao terceiro e último quesito formulado, realizou-se a análise dos fatos e documentos trazidos aos autos, à luz das regras de interpretação das disposições testamentárias e dos negócios jurídicos. Aplicaram-se também, por analogia, as normas relativas à doação com encargo, bem como a jurisprudência acerca das cláusulas testamentárias restritivas.

102 FARIAS, Cristiano Chaves de; ROSENVALD, Nelson. Curso de direito civil: parte geral e LINDB. 19. ed. Salvador: JusPodivm, 2021. p. 697. 
Assim, conforme o apresentado, constata-se que:

a) o encargo ou ônus imposto à legatária é em muito superior ao valor do legado ou bônus auferidos pela legatária, o que acaba por subverter a lógica pretendida pelo testador;

b) dado o caráter restritivo do encargo testamentário, ele não poderá ser mantido de maneira perpétua, sendo necessário estabelecer um prazo final para seu cumprimento, em atenção à razoabilidade e boa-fé da relação jurídica;

c) é possível o levantamento do encargo quando seu cumprimento for de encontro ao objetivo da instituição do legado, notadamente para que atenda à sua função social;

d) tendo a legatária cumprido integralmente os encargos da forma como expressamente previsto na deixa testamentária durante muitos anos, como visto, é possível aplicar ao caso a teoria do adimplemento substancial.

Conclui-se, então, que é possível o levantamento ou a mitigação dos encargos impostos à doação ou ao legado. No caso em tela, deve-se considerar que os encargos impostos à XXX, diante do contexto fático apresentado, analisado à luz das premissas interpretativas expostas, já foram integralmente cumpridos, restando esvaziada eventual exigibilidade de tais ônus.

\section{Conclusão}

Tendo em vista o estudo aqui apresentado, conclui-se que:

a) a cessão de direitos hereditários apresentada pelo autor é um negócio jurídico nulo, porquanto não atende à forma prescrita em lei, possui objeto impossível, além de carecer, o cedente, de capacidade, consubstanciada na sua ilegitimidade para o ato;

b) o autor da demanda em análise não possui legitimidade ad causam para propositura da ação que busca revogação de deixa testamentária por descumprimento do encargo, porquanto não pode ser considerado herdeiro legítimo ou testamentário do autor da herança, o que implica também a ausência de interesse de agir;

c) é possível o levantamento ou a mitigação dos encargos impostos à doação ou ao legado e, no caso em tela, deve-se considerar que os encargos impostos à XXX, diante do contexto fático apresentado, analisado à luz 
das premissas interpretativas expostas, já foram integralmente cumpridos, restando esvaziada eventual exigibilidade de tais ônus.

É o parecer.

Informação bibliográfica deste texto, conforme a NBR 6023:2018 da Associação Brasileira de Normas Técnicas (ABNT):

ROSA, Conrado Paulino da; FRANKE, Denise Neulia; COELHO, Fernanda Rosa. Requisitos de validade de cessão de direitos hereditários - Legitimidade ad causam para ação revogatória de deixa testamentária por descumprimento de encargo - Exoneração de encargo testamentário - Limites temporais e materiais dos encargos. Revista Brasileira de Direito Civil-RBDCivil, Belo Horizonte, v. 29, p. 205-240, jul./set. 2021. Parecer.

Recebido em: 16.08.2021

Aprovado em:13.10.2021 